Original Article

\title{
Effects of High Diluted Solutions of Palicourea marcgravii St Hill in Rats Poisoned by Aqueous Extracts of This Plant
}

\author{
Luiz Figueira Pinto ${ }^{1}$, Lilian Rangel de Castilhos ${ }^{2}$, João Telhado ${ }^{1}$, \\ Ticiana do Nascimento França ${ }^{1}$, Marilene de Farias Brito ${ }^{1}$, \\ Paulo Vargas Peixoto ${ }^{1}$.
}

(1) Federal Rural University of Rio de Janeiro, RJ, Brazil, (2) University Centre of Vila Velha, ES, Brazil

\begin{abstract}
Palicourea marcgravii, a shrub causing sudden death in cattle, is a major cause of economic loss to breeders in Brazil. The aim of the present study was to evaluate the effects of high diluted solutions $6 \mathrm{cH}$ and $30 \mathrm{cH}$ of $P$. marcgravii, on the development of tolerance to the toxic effects of this plant. 14 adult Wistar rats were divided into 3 test groups. AE (aqueous extract) group was composed of 4 rats receiving aqueous extract of $P$. marcgravii intragastrically at a dose of $2 \mathrm{~g} / \mathrm{kg}$. Groups $\mathrm{HD}_{6} \mathrm{AE}$ and $\mathrm{HD}_{30} \mathrm{AE}$ comprised 5 rats each. Animals in these groups received $1 \mathrm{~mL}$ of $6 \mathrm{cH}$ and $30 \mathrm{cH}$ solutions of $P$. marcgravii respectively by oral route 3 times a day, for 8 days. At the end of this period, they were intragastrically intoxicated with $2 \mathrm{~g} / \mathrm{kg}$ of aqueous extract of $P$. marcgravii, receiving the corresponding high diluted preparation hourly until death. Main symptoms were nervous excitability and convulsions. Even though the times for onset of the first clinical signs, convulsions and death was slightly longer in the animals in group $\mathrm{HD}_{30} \mathrm{AE}$ when compared to group $\mathrm{AE}$, no evidence indicating that the highly diluted preparations increase tolerance to intoxication by $P$. marcgravii was found.
\end{abstract}

Keywords: Palicourea marcgravii; Intoxication; Isopathy; High dilutions; Wistar rats.

\section{Introduction}

Livestock production in Brazil has annual losses of around 1,000,000 adult bovines due to vegetal poisoning. Approximately half of these are caused by ingestion of Palicourea marcgravii St. Hill (erva-derato), associated to sudden death [1].

Pharmacological studies aiming at a therapeutic solution for the recovery of animals poisoned by $P$. marcgravii have not been fully successful [1-3], even though the active ingredient, or one of the major toxic components of this plant, is known to be monofluoroacetic acid [4-7]. Homeopathic therapeutics has been recommended for organic livestock production [8]. However, experimental studies using high dilution preparations have yielded controversial results partially due to possible placebo effect [9-14]. For this reason, more research in this area is needed.
This study aimed to evaluate the effects of high diluted preparations of extract of $P$. marcgravii on the development of tolerance to the toxic effects of this plant in rats.

\section{Material and Methods}

Palicourea marcgravii St. Hill (Figure 1) was collected in the city of Valença, Rio de Janeiro, Brazil. It was identified and cataloged as RG: 22,971 in the Herbarium of the Department of Botany at Federal Rural University of Rio de Janeiro (UFRRJ).

Extraction of aqueous extracts from the leaves of $P$. marcgravii $(\mathrm{Pm})$ in flowering and fruiting stages as well as the preparation of diluted and agitated solutions following Hahnemannian centesimal scale in dilutions $6 \mathrm{cH}$ and $30 \mathrm{cH}(P m 6 \mathrm{cH}$ and $\mathrm{Pm} 30 \mathrm{cH}$, respectively) were performed at the SchoolPharmacy of the Hahnemannian Institute of Brazil, 
Rio de Janeiro, following the Brazilian Homeopathic Pharmacopoeia [15].

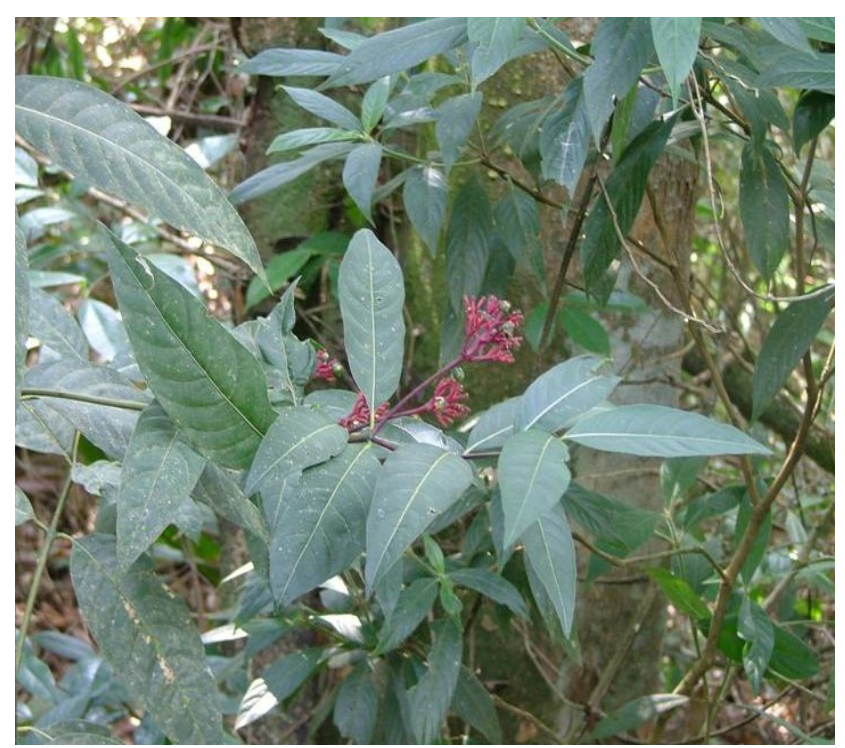

Figure 1: Palicourea marcgravii during flowering and fruiting.

14 healthy female Wistar rats between 6 and 7 weeks old and weighing 90 to 160 grams were used. Animals were kept under light during the day and in the dark at night, at temperature $22-24^{\circ} \mathrm{C}$, with water and feed ad libitum during the whole experimental period.

All animals were kept under observation for one week before the onset of the experiment to allow for environmental adaptation and evaluation of the health status. They were deprived of water and food 24 hours before the administration of aqueous extract of $\mathrm{Pm}$. Rats were randomly divided into the following groups: $\mathrm{AE}$ (aqueous extract), $\mathrm{HD}_{6} \mathrm{AE}$ (high dilution $6 \mathrm{cH}+$ aqueous extract), and $\mathrm{HD}_{30} \mathrm{AE}$ (high dilution $30 \mathrm{cH}+$ aqueous extract).

Group AE was composed of 4 animals that received a single dose of $2 \mathrm{~g} / \mathrm{kg}$ body weight $P$. marcgravii aqueous extract by intragastric route. Groups $\mathrm{HD}_{6} \mathrm{AE}$ and $\mathrm{HD}_{30} \mathrm{AE}$ comprised 5 animals each; these received $1 \mathrm{ml}$ of $\mathrm{Pm} 6 \mathrm{cH}$ and $\mathrm{Pm} 30 \mathrm{cH}$ solutions respectively by oral route, 3 times a day for 8 days.

On the $8^{\text {th }}$ day, one hour after the administration of the high diluted solutions, animals received $P$. marcgravii aqueous extract in a single dose of $2 \mathrm{~g} / \mathrm{kg}$ body weight by intragastric route. 30 minutes after administering the aqueous extract, animals were given $1 \mathrm{ml}$ of the respective high diluted preparation at hourly intervals for 2 to 9 hours.

Clinical evaluation of the animals took the following parameters into account: weight, food ingestion, motor activity, piloerection, cyanosis of extremities, hypothermia, type of breathing, shivering, pruritus, neurological depression, convulsions and death.

All animals that died were necropsied at the end of the experimental period and macroscopic alterations were recorded. Samples of brain, heart, lungs, liver, kidneys, stomach and intestine were subjected to histological analysis. The animals that did not die were euthanized in a chamber saturated with the inhalational general anesthetic Halothane ${ }^{\circledR}$.

This work was approved by Ethics Committee of the Veterinary Institute at UFRRJ.

\section{Results}

None of the animals in groups $\mathrm{HD}_{6} \mathrm{AE}$ and $\mathrm{HD}_{30} \mathrm{AE}$ showed any clinical alteration and they all exhibited normal behavior during the 7 days of administration of the respective high diluted solution. The first clinical signs of poisoning after administration of $P$. marcgravii aqueous extract appeared within 15 to 45 minutes in group $\mathrm{AE}, 30$ to 37 minutes in group $\mathrm{HD}_{6} \mathrm{AE}$ and 50 to 70 minutes in $\mathrm{HD}_{30} \mathrm{AE}$. Animals in all groups exhibited reduction in mobility, piloerection, dyspnea, cyanosis of the extremities, hypothermia, shivering and hyperexcitability (Table 1).

Clinical manifestations of convulsive crisis, characterized by tonic and clonic spasms, occurred in all the animals that received $P$. marcgravii aqueous extract but for one rat in group $\mathrm{AE}$ and 2 rats in group $\mathrm{HD}_{30} \mathrm{AE}$. The time for onset of convulsions was longer for animals in groups $\mathrm{HD}_{6} \mathrm{AE}$ and $\mathrm{HD}_{30} \mathrm{AE}$ as shown in Table 2. On the other hand, handling of these animals for repeated administration of the high diluted solutions resulted, in some cases, in convulsive crisis and, sometimes, death.

The administration of $P$. marcgravii aqueous extract caused death always in a hyperacute manner, as observed in 1 of the 4 animals in group $\mathrm{AE}$ group, 3 of the 5 rats in group $\mathrm{HD}_{6} \mathrm{AE}$ group, and 2 of the 5 components of group $\mathrm{HD}_{30} \mathrm{AE}$. However, the animals that had received the high diluted solutions survived a little longer (Table 2). 
Table 1: Experimental poisoning of rats in groups $\mathrm{AE}, \mathrm{HD}_{6} \mathrm{AE}$ and $\mathrm{HD}_{30} \mathrm{AE}$, which received Palicourea marcgravii aqueous extract.

\begin{tabular}{|c|c|c|c|c|c|c|c|c|c|c|c|}
\hline \multirow[b]{2}{*}{$\underset{\mathfrak{Z}}{\overparen{Z}}$} & \multirow[b]{2}{*}{$\begin{array}{l}\stackrel{2}{\Xi} \\
\vdots \\
\dot{d}\end{array}$} & \multirow{2}{*}{ 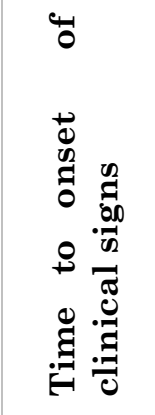 } & \multirow[b]{2}{*}{ 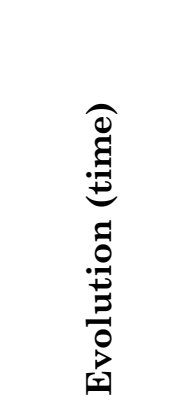 } & \multirow[b]{2}{*}{ 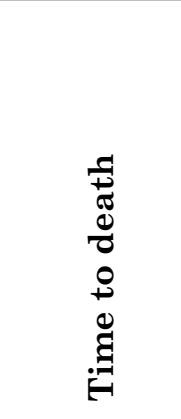 } & \multicolumn{7}{|c|}{ Clinical signs of poisoning (a) } \\
\hline & & & & & 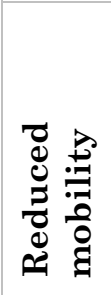 & 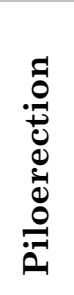 & 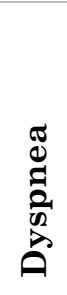 & 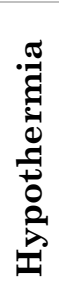 & 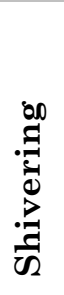 & 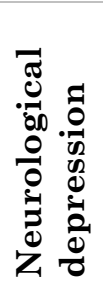 & 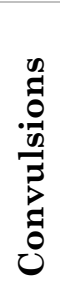 \\
\hline $\mathbf{R} 1$ & $\mathrm{AE}$ & $\sim 45 \mathrm{~min}$ & \multicolumn{2}{|c|}{ Euthanasia after $24 \mathrm{~h}$} & + & + & + & + & + & + & + \\
\hline $\mathbf{R 2}$ & $\mathrm{AE}$ & $\sim 35 \mathrm{~min}$ & $1 \mathrm{~h} 15 \mathrm{~min}$ & $1 \mathrm{~h} 50 \mathrm{~min}$ & + & + & + & + & + & + & + \\
\hline R3 & $\mathrm{AE}$ & $\sim 15 \mathrm{~min}$ & \multicolumn{2}{|c|}{ Euthanasia after $24 \mathrm{~h}$} & - & + & + & - & + & + & - \\
\hline R4 & $\mathrm{AE}$ & $\sim 35 \mathrm{~min}$ & \multicolumn{2}{|c|}{ Euthanasia after $24 \mathrm{~h}$} & - & + & + & - & + & + & + \\
\hline R40 & $\mathrm{HD}_{6} \mathrm{AE}$ & $\sim 30 \mathrm{~min}$ & \multicolumn{2}{|c|}{ Euthanasia after $24 \mathrm{~h}$} & + & + & + & + & + & + & + \\
\hline R41 & $\mathrm{HD}_{6} \mathrm{AE}$ & $\sim 30 \mathrm{~min}$ & $2 \mathrm{~h} 05 \mathrm{~min}$ & $2 \mathrm{~h} 35 \mathrm{~min}$ & + & + & + & + & - & + & + \\
\hline R42 & $\mathrm{HD}_{6} \mathrm{AE}$ & $\sim 32 \mathrm{~min}$ & \multicolumn{2}{|c|}{ Euthanasia after $24 \mathrm{~h}$} & + & + & + & + & + & + & + \\
\hline R43 & $\mathrm{HD}_{6} \mathrm{AE}$ & $\sim 34 \mathrm{~min}$ & 1h30min & $2 \mathrm{~h} 04 \mathrm{~min}$ & + & + & + & + & - & + & + \\
\hline R44 & $\mathrm{HD}_{6} \mathrm{AE}$ & $\sim 37 \mathrm{~min}$ & $3 \mathrm{~h} 41 \mathrm{~min}$ & $4 \mathrm{~h} 18 \mathrm{~min}$ & + & + & + & + & + & + & + \\
\hline $\mathbf{R 4 5}$ & $\mathrm{HD}_{30} \mathrm{AE}$ & $\sim 58 \mathrm{~min}$ & $10 \mathrm{~h} 15 \mathrm{~min}$ & $11 \mathrm{~h} 13 \mathrm{~min}$ & + & + & + & + & + & + & + \\
\hline R46 & $\mathrm{HD}_{30} \mathrm{AE}$ & $\sim 59 \mathrm{~min}$ & \multicolumn{2}{|c|}{ Euthanasia after $24 \mathrm{~h}$} & + & + & + & + & + & + & + \\
\hline R47 & $\mathrm{HD}_{30} \mathrm{AE}$ & $\sim 63 \mathrm{~min}$ & \multicolumn{2}{|c|}{ Euthanasia after $24 \mathrm{~h}$} & + & + & + & + & + & + & - \\
\hline R48 & $\mathrm{HD}_{30} \mathrm{AE}$ & $\sim 58 \mathrm{~min}$ & $3 \mathrm{~h} 35 \mathrm{~min}$ & $4 \mathrm{~h} 33 \mathrm{~min}$ & + & + & + & + & - & + & + \\
\hline $\mathbf{R 4 9}$ & $\mathrm{HD}_{30} \mathrm{AE}$ & $\sim 70 \mathrm{~min}$ & \multicolumn{2}{|c|}{ Euthanasia after $24 \mathrm{~h}$} & + & + & + & + & + & + & - \\
\hline
\end{tabular}

(a) + manifested clinical sign, - clinical sign absent

Table 2: Clinical parameters of convulsions in rats poisoned by Palicourea marcgravii aqueous extract. 


\begin{tabular}{|c|c|c|c|c|c|}
\hline & Convulsi & arameters & & & \\
\hline Animal & Group & $\begin{array}{l}\text { Number of } \\
\text { convulsions }\end{array}$ & $\begin{array}{l}\text { Time for onset of } \\
\text { convulsions }\end{array}$ & $\begin{array}{l}\text { Interval } \\
\text { between } \\
\text { convulsions } \\
\text { (time) }\end{array}$ & $\begin{array}{l}\text { Convulsion } \\
\text { score (0 to } 3)\end{array}$ \\
\hline $\mathrm{R} 1$ & $\mathrm{AE}$ & 4 & $55 \mathrm{~min}$ & $\begin{array}{l}10 \mathrm{~min}, \quad 30 \mathrm{~min} \\
\text { and } 2 \mathrm{~h} 45 \mathrm{~min}\end{array}$ & 3 \\
\hline $\mathrm{R} 2$ & $\mathrm{AE}$ & 3 & $40 \mathrm{~min}$ & 15 and $30 \mathrm{~min}$ & 3 \\
\hline R3 & $\mathrm{AE}$ & 0 & - & - & 0 \\
\hline $\mathrm{R} 4$ & $\mathrm{AE}$ & 1 & $59 \mathrm{~min}$ & - & 3 \\
\hline R40 & $\mathrm{HD}_{6} \mathrm{EA}$ & 1 & $3 \mathrm{~h} 48 \mathrm{~min}$ & - & 2 \\
\hline R41 & $\mathrm{HD}_{6} \mathrm{EA}$ & 1 & $2 \mathrm{~h} 33 \mathrm{~min}$ & - & 3 \\
\hline R42 & $\mathrm{HD}_{6} \mathrm{EA}$ & 1 & $2 \mathrm{~h} 45 \mathrm{~min}$ & - & 3 \\
\hline R43 & $\mathrm{HD}_{6} \mathrm{EA}$ & 4 & 1h33min & 10 to $15 \mathrm{~min}$ & 3 \\
\hline R44 & $\mathrm{HD}_{6} \mathrm{EA}$ & 2 & $1 \mathrm{~h} 45 \mathrm{~min}$ & $2 \mathrm{~h} 27 \mathrm{~min}$ & 3 \\
\hline $\mathrm{R} 45$ & $\mathrm{HD}_{30} \mathrm{EA}$ & 3 & $4 \mathrm{~h} 09 \mathrm{~min}$ & $\begin{array}{l}6 \mathrm{~h} 3 \mathrm{~min} \text { and } 45 \\
\min \end{array}$ & 2 \\
\hline R46 & $\mathrm{HD}_{30} \mathrm{EA}$ & 1 & $3 \mathrm{~h} 50 \mathrm{~min}$ & - & 2 \\
\hline R47 & $\mathrm{HD}_{30} \mathrm{EA}$ & 0 & - & - & 0 \\
\hline R48 & $\mathrm{HD}_{30} \mathrm{EA}$ & 4 & $3 \mathrm{~h} 19 \mathrm{~min}$ & $\begin{array}{l}30, \quad 11 \text { and } 7 \\
\min \end{array}$ & 3 \\
\hline R49 & $\mathrm{HD}_{30} \mathrm{EA}$ & 0 & - & - & 0 \\
\hline
\end{tabular}

The main pathological finding in animals in groups $\mathrm{AE}, \mathrm{HD}_{6} \mathrm{AE}$ and $\mathrm{HD}_{30} \mathrm{AE}$ was hepatic congestion, although some animals also showed signs of cardiac dilatation. Histological analysis revealed various degrees of congestion in the liver, lungs and spleen. 7 animals exhibited the most characteristic and conspicuous lesion, hydropic-vacuolar degeneration of renal distal convoluted tubules (Figure 2). Significant histological alterations were not observed in other organs.

\section{Discussion}

In this study, the clinical manifestations of poisoning and hyperacute death of rats were similar to those found in rats and Guinea pigs experimentally poisoned by $P$. marcgravii [16], and in other animals poisoned by sodium monofluoroacetate $[1,5,7,17]$. In these cases, hyperacute death occurs due to interruption of the aerobic metabolism, which results in accumulation of large amounts of citrate in the tissues and inhibition of adenosine triphosphate production $[6,18]$. This indicates that the cellular dysfunction caused by poisoning by $P$. marcgravii is irreversible, thus complicating therapeutic recovery as verified in the literature [3].

In this experiment, the animals that had previously received a high diluted solution of $P$. marcgravii showed the same clinical picture of hyperacute death observed in the animals in group AE. Longer times for onset of the first clinical signs of poisoning, convulsions and death were observed in the animals in these groups, especially in those that received Pm30cH solution.

Drugs [3] or plant extracts $[19,20]$ are considered effective when they promote an increase in the time for onset of convulsions. However, in this experiment, the number of animals employed was considered too small to establish whether high 
diluted solutions of $P$. marcgravii have indeed anticonvulsant activity. On the other hand, it may be possible that manipulation related to repeated oral administration of the high diluted solutions contributed to worsen the effects of poisoning as data from literature indicate that exercise worsens the clinical picture of convulsions and can precipitate the death of animals $[1,21]$.

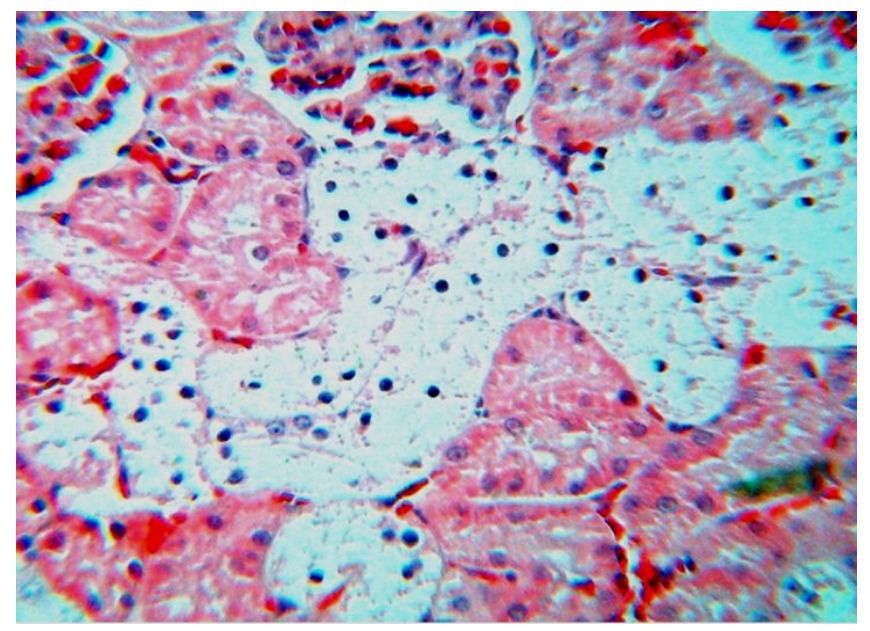

Figure 2: Hydropic-vacuolar degeneration of renal distal convoluted tubules in a rat poisoned by Palicourea marcgravii aqueous extract. Obj. 25x.

\section{Conclusion}

In this study, no evidence indicating that high diluted solutions of $P$. marcgravii increase resistance to poisoning by the aqueous extract of this plant was found. However, it is not possible to discard the possibility that ingestion of these solutions prior to poisoning exerts an anticonvulsant effect.

\section{References}

[1] Tokarnia CH, Döbereiner J, Peixoto PV, editors. Plantas tóxicas do Brasil. Rio de Janeiro: Helianthus; 2000.

[2] Górniak SL, Palermo-Neto J, Spinosa HS. Effects of CNS depressant drugs on acute intoxication from Palicourea marcgravii (St Hill) in rats. Vet Hum Toxicol. 1993; 35(1): 19-21.

[3] Górniak SL, Palermo-Neto J, Spinosa HS. Effects of acetamide on experimentally-induced Palicourea marcgravii (St Hill) poisoning in rats. Vet Hum Toxicol. 1994; 36(2): 101-102.

[4] Tokarnia CH, Döbereiner J. Intoxicação por Palicourea marcgravii (Rubiaceae) em bovinos no Brasil. Pesq Vet. Bras. 1986; 6(3): 73-92.
[5] Eckschmidt M, Brizolla M, Tarragá DP, Palermo-Neto J. Is monofluoacetic acid the active neurotoxic principle in Palicourea marcgravii (St. Hill) leaves? Brazilian Journal of Medical and Biol Res. 1989; 22: 975-977.

[6] Krebs HC, Kemmerling W, Habermehl G. Qualitative and quantitative determination of fluoroacetic acid in Arrabidea bilabiata and Palicourea marcgravii by 19F-NMR spectroscopy. Toxicon. 1994; 32(8): 909-913.

[7] Moraes-Moreau RL, Haraguchi M, Morita HE, Palermo-Neto J. Chemical and biological demonstration of the monofluoroacetate in the leaves of Palicourea marcgravii. Brazilian Journal of Medicine and Biol Res. 1995; 28(6): 685-692.

[8] Brasil, Ministério da Agricultura, Pecuária e Abastecimento. Decreto $\mathrm{n}^{\circ} 6.323$, de 27 de dezembro de 2007. Publicado no Diário Oficial da União de 28/12/2007, seção 1, página 2. Regulamenta a Lei n ${ }^{\circ}$ 10.831, de 23 de dezembro de 2003, que dispõe sobre a agricultura orgânica, e dá outras providências [cited 2008 Out 21]. Available from:

http://www.agricultura.gov.br.

[9] Linde K, Clausius N, Ramirez G, Melchart D, Eitel F, Hedges LV, et al. Are the clinical effects of homoeopathy placebo effects? A meta-analysis of placebo-controlled trials. Lancet. 1997; 350: 834-843.

[10] Ernst E, Pittler MH. Efficacy of homeopathic Arnica: a systematic review of placebo-controlled clinical trials. Arch Surg [online]. 1998 [cited 2007 Aug 22]. [about 5 p]. Available from:

http://archsurg.ama-ssn.org/cgi/reprint/133/11/1187.

[11] Lewith GT, Watkins AD, Hyland ME, Shaw S, Broomfield JA, Dolan G, et al. Use of ultramolecular potencies of allergen to treat asthmatic people allergic to house dust mite: double blind randomized controlled clinical trial. British Medical Journal [online]. 2002 [cited 2007 Sep 30]; 324. [about 2 p]. Available from:

http://www.bmj.com/cgi/content/abstract/324/7336/5 $\underline{20}$.

[12] Brien S, Lewith G, Bryant T. Ultramolecular homeopathy has no observable clinical effects: a randomized double-blind, placebo-controlled proving trial of Belladona 30C. Br J Clin Pharmacol. 2003; 56: 562-568.

[13] Shang A, Huwiler-Muntener K, Nartey L, Juni P, Dorig S, Sterne JAC, et al. Are the clinical effects of homoeopathy placebo effects? Comparative study of placebo-controlled trials of homoeopathy and allopathy. Lancet. 2005; 366(27): 726-732.

[14] Queiroz AO, Xavier SCC, Faria KG, Bernardo RR, Leitão TC. A. Avaliação do bioterápico Trypanossoma cruzi 30DH: um estudo in vivo. Cultura Homeopática. 2006; 5(17): 9-13. 
[15] Brasil, Ministério da Saúde. Farmacopéia Homeopática Brasileira. 2nd ed. São Paulo: Atheneu; 1997.

[16] Gorniak SL. Palicourea marcgravii: estudo em animais de laboratório [Dissertation (Master of Science)]. São Paulo: Medicine Veterinary School, University of São Paulo, 1986.

[17] Kemmerling W. Toxicity of Palicourea marcgravii: combined effects of fluoroacetate, $\mathrm{N}$ methyltyramine and 2-methyltetrahydro-betacarboline. Z Naturforsch. 1996; 51(1-2): 59-64.

[18] Goncharov NV, Jenkins RO, Rachilov AS. Toxicology of fluoreacetate: a review, with possible directions for therapy research. J Appl Toxicol [online]. [cited 2005 Dez 12]; 26(2): 148-161. [DOI: 10.1002/jat.1118]. Available from: http://www3.interscience.wiley.com/cgibin/fulltext/112136383/PDFSTART.

[19] Pérez de Alejo JL, Miranda R, Rodriguez G. Actividad anticonvulsivante (antiepileptica) del extracto fluido de Indigofera suffruticosa (añil cimarron). Rev Cubana Plant Med. 1996; 1(1): 7-10.

[20] Quintans-Júnior LJ, Almeida RN, Falcão ACGM, Agra MF, Souza MFV, Barbosa-Filho JM. Avaliação da atividade anticonvulsivante de plantas do Nordeste brasileiro. Acta Farm Bonaerense. 2002; 21(3): 179-184.

[21] Tokarnia CH, Peixoto PV, Döbereiner J. Intoxicação experimental por Palicourea marcgravii (Rubiaceae) em caprinos. Braz. J Vet Res. 1991; 11(3): 65-70.

(c)) BY-NC-ND Licensed to GIRI

Support: authors declare that this study received no funding Conflict of interest: authors declare there is no conflict of interest

Received: 27 Aug 2008; Revised 30 Nov 2008; Published: 19 Dec 2008

Erratum: 30 Dec 2008. (http://www.feg.unesp.br/ ojs/zacha_ijhdr/erratum/?v=7\&i=25\&pi=193)

Correspondence author: Luiz Figueira Pinto, luizfigueira@ufrrj.br

How to cite this article: Pinto LF, Castilhos LR, Telhado J, França TN, Brito MF, Peixoto PV. Effects of High Diluted Solutions of Palicourea marcgravii St Hill in Rats Poisoned by Aqueous Extracts of This Plant. Int J High Dilution Res [online]. 2008 [cited YYYY Mmm DD]; 7(25): 193-198. Available from:

http://www.feg.unesp.br/ ojs/index.php/ijhdr/article/view/301/372. 